\title{
György Kurtág's Hungarian Identity and The Sayings of Péter Bornemisza (1963-1968)*
}

\author{
Anna DALOS \\ Institute for Musicology \\ Research Centre for the Humanities \\ Hungarian Academy of Sciences \\ Táncsics Mihály u. 7, H-1014 Budapest, Hungary \\ E-mail: dalos.anna@btk.mta.hu
}

(Received: September 2012; accepted: March 2013)

\begin{abstract}
After the political and cultural seclusion of the 1950s young Hungarian composers turned to Western European new music. While learning contemporary compositional techniques they were searching for a new Hungarian identity in music. The musicological discourse about new Hungarian music concentrated on the 'Hungarianness' of their music too. Composers used Hungarian literary texts, and referred to Hungarian music culture with musical allusions. They inherited the idea of the combination of the up-to-date Western European compositional techniques with the old Hungarian tradition from Kodály and Bartók, i.e. they were aware of the primacy of tradition. György Kurtág's (1926) concerto for soprano and piano, The Sayings of Péter Bornemisza (1963-1968) represented for Hungarian musicians the paradigmatic example of new Hungarian music, modern and traditional at the same time. It was based on an old Hungarian text from the $16^{\text {th }}$-century, like Kodály's Psalmus Hungaricus (1923). The vocal part, however, refers to Webern's melodic concept, the piano part follows Stockhausen's piano writing, and Kurtág quotes neither Hungarian folk music nor old Hungarian art music. The paper investigates by means of musical analysis the question why contemporaries felt that Kurtág's piece represents unambiguously a Hungarian identity. Kurtág - as well as his contemporaries - uses symbols, allusions connected to certain words and word-paintings while concentrating on the picturesque elements of music. The source of this compositional attitude is Kodály's oeuvre, foremost the Psalmus Hungaricus. From this angle Kurtág's The Sayings stands for the new-old Hungarian musical tradition.
\end{abstract}

Keywords: György Kurtág, Péter Bornemisza, modernity, word-painting, post-Stalinism, Zoltán Kodály, Ernő Lendvai

* The preparation of this study was kindly supported by the Lendület Research Grant of the Hungarian Academy of Sciences. 
In his essay, Kurtág, Modernity, Modernisms Alan Williams hints at the most peculiar feature of György Kurtág's music, namely the composer's attraction toward having double meaning in his works. ${ }^{1}$ This ambiguity manifests itself equally in his relation to tradition and avantgarde, as well as in the use of tonality and atonality or in the unanimity of the content and in the obscure references. Besides these features, as Williams put it, it was Kurtág's unusual individualism that crossed the succes of Kurtág's first opus magnum, The Sayings of Péter Bornemisza in Darmstadt in 1968. ${ }^{2}$ For Rachel Beckles Willson the concerto's complete failure was due to its seeming conservatism, ${ }^{3}$ while Stephen Walsh held that Darmstadt composers, if they had known that the composition represented an unparalleled radicalism in self-examination, they would have felt ashamed instead of neglecting the piece. ${ }^{4}$ I intend to give a different answer to the question why The Sayings have failed in Darmstadt. My point is, that the concerto for soprano and piano written between 1963 and 1968 stands strongly in the Hungarian tradition, not only because its text is in Hungarian, thus one cannot fully understand the work without understanding the text, but because its compositional devices and solutions were inherited - besides European music history and Western avantgarde - from the Hungarian musical tradition of the $20^{\text {th }}$ century. Furthermore, the composition wouldn't have been born outside of the context of politics and cultural policies in the early Kádár-era. The ambiguity of Kurtág's musical language is connected to the practice of double speech in the Hungary of the 1960 s.

Kurtág put together the libretto of The Sayings from different writings of the $16^{\text {th }}$-century poet-preacher, Péter Bornemisza, and created a four-part cycle from it, titled Confession (I), Sin (II) Death (III) and Spring (IV). The four parts reflect the structure of the classical symphony, with the second part, Sin, representing the scherzo, while the third part, Death, is a lyrical slow part including a funeral music. ${ }^{5}$ However the parts - except for the first - are built from shorter movements following the short texts, and are sometimes separated by intermezzi for the piano. Kurtág calls his cycle concerto alluding to Heinrich Schütz's Kleine geistliche Konzerte (written between 1636 and 1639), where one or more solo voices are accompanied by a keyboard instrument. Kurtág's main model must have been Schütz's Eile mich, Gott, zu erretten (SWV 282), to the text of which

1. Alan E. Williams, "Kurtág, Modernity, Modernisms," in Perspectives on Kurtág, ed. Rachel Beckles Willson and Alan E. Williams (= Contemporary Music Review 20/2-3 [2001]), 52.

2. Williams, Kurtág, 53.

3. Rachel Beckles Willson, György Kurtág: The Sayings of Péter Bornemisza, Op. 7. A 'Concerto' for Soprano and Piano (Aldershot: Ashgate, 2003), 133.

4. Stephen Walsh, "György Kurtág: The Sayings of Péter Bornemisza, Op. 7: A Concerto for Soprano and Piano," Music and Letters 87/4 (November 2006), 668.

5. György Kroó, "Kurtág György: Bornemisza Péter mondásai op. 7. Concerto szoprán hangra és zongorára" [György Kurtág: The Sayings of Péter Bornemisza op. 7. Concerto for soprano and piano], in Miért szép századunk zenéje? [Why is the music of our time beautiful?], ed. idem (Budapest: Gondolat, 1974), 319-367, here 326-327. 
Zoltán Kodály's Psalmus Hungaricus is related. One of the first analysts of The Sayings, György Kroó pointed out, that Kodály's Psalmus must have been a referential point for Kurtág when writing The Sayings. Kurtág used the writings of a $16^{\text {th }}$-century preacher, as Kodály had done with the paraphrase of Psalm 55 by Mihály Kecskeméti Vég (also a $16^{\text {th }}$-century Hungarian preacher). Kroó also maintained that Kurtág's composition fulfilled a role in the Hungarian new music of the 1960s similar to what Kodály's Psalmus had played forty years earlier. ${ }^{6}$

Certainly, Kodály's choice of text was personally motivated. By setting the words of King David's Psalm no. 55, Complaint about the friend's treachery, Kodály narrated the calumnious trial at Academy of Music after the fall of the Hungarian Soviet Republic in 1919. Notwithstanding, the Psalmus Hungaricus became a symbol of the insulted, broken Hungarian nation after the Trianon Treaty which caused the loss of huge territories of old Hungary. There might be a similar personal background in Kurtág's choice of Péter Bornemisza. Margaret McLay assumes, that the concerto is in part an autobiographical composition. ${ }^{7}$ Kurtág characterizes himself as a lazy man, and the only sin mentioned concretely in The Sayings is laziness. ${ }^{8}$ Kurtág recalls the notion of idleness in the fourth movement of the second part, depicting it with a yawn-like glissando (Example 1). ${ }^{9}$ Apart from this autobiographical reference it is conspicuous that the text, mainly in the first three parts, is full of a general disgust with the world and the life. Though The Sayings has been one of Kurtág's most analysed compositions, no investigator tried to find the reason of this disgust. What might have aroused the aversions of the preacher of The Sayings, surely to be considered the projection of the composer himself?

\section{EXAMPLE 1 Kurtág, The Sayings, II/4, bar 1}

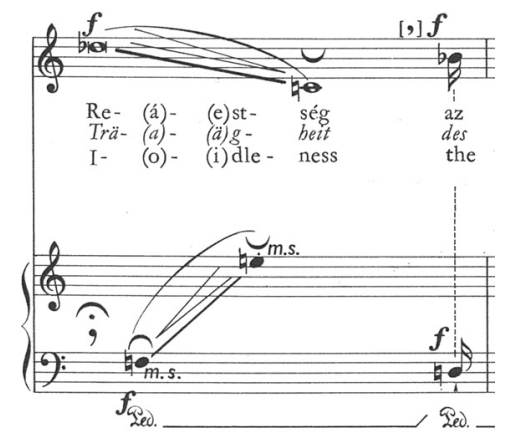

6. Ibid., 319-320.

7. Margaret McLay, “Kurtág’s Bornemisza Concerto,” The Musical Times 129/1749 (November 1988), 580.

8. Ibid.

9. The music examples from Kurtág's The Sayings are published with the permission of Universal Edition Wien. 
The disgust was of minor importance in the contemporary Hungarian reception of the work, too. Hungarian critics, who - like János Kárpáti - emphasized the importance of the ethical message of the composition, concentrated on the last part of The Sayings. ${ }^{10}$ Spring appeared in this context as a symbol of hope. János Breuer worded that "it is a music as brutally truthful, as Péter Bornemisza, the irate preacher of the $16^{\text {th }}$ century who confronted his contemporaries rudely with everything he believed to be the truth." ${ }^{11}$ But after Sin and Death, "after the apocalyptic experiences a resigned smile, a humanistic confession ends the work."12 György Kroó spoke also about Kurtág's dream about the arrival of spring after the diabolic fugue: Kurtág arrives "at radiant crystalline structures so that after high-mindedly summing up the whole life he would jump over to the spring of the thirds and sixths, to the promise of pentatony... Kurtág's music promises that the contract with the devil can be cancelled. The blue of the sky glints again above a little field of European music."13

As Rachel Beckles Willson put it, this formulation based on the dichotomy of chromaticism and diatony has its source in the hermeneutical approaches of Hungarian musical thinking, paradigmatically appearing in Ernő Lendvai's Bartók-interpretations. ${ }^{14}$ Kurtág studied intensively Lendvai's theory when working on The Sayings. ${ }^{15}$ Lendvai connected the use of dodecaphony to the composer Adrian Leverkühn created by Thomas Mann in his novel Doctor Faustus. ${ }^{16}$ In the spirit of Lendvai, Kroó as well as Kárpáti associated the use of dodecaphony in The Sayings with the above mentioned contract with the devil. ${ }^{17}$ In this respect dodecaphony became the symbol of diabolical temptation. ${ }^{18}$ That means that not only the hopeful ending is determining in the interpretation of the composition, but also the mysterious demonic temptation which precedes the beginning of the piece, one might say: which precedes the act of composition, i.e. something that remains musically unexpressed. To understand the meaning of this suppressed temptation, it is instructive to analyse the thoughts which remained unworded in the writings of the critics, as these can reveal us the nature of the suppressed temptation. They may be part and parcel of the same discourse as Kurtág's composition.

10. János Kárpáti, “Kurtág György: Bornemisza Péter mondásai - Concerto szoprán hangra és zongorára op. 7" [György Kurtág: The Sayings of Péter Bornemisza - Concerto for soprano and piano op. 7], Magyar Zene 15/2 (June 1974), 115-133.

11. János Breuer, “Új magyar muzsika” [New Hungarian Music], Népszabadság 26/242 (15 October 1968), 7.

12. Ibid.

13. György Kroó, “1968. október 11.”, in A mikrofonnál Kroó György. Új Zenei Újság 1960-1980 [György Kroó at the microphone. New Musical Journal] (Budapest: Zenemúkiadó, 1981), 129.

14. Rachel Beckles Willson, Ligeti, Kurtág, and Hungarian Music during the Cold War (Cambridge: Cambridge University Press, 2007), 107.

15. Ibid.

16. Kárpáti, “The Sayings”, 117., Kroó, "Bornemisza”, 366-367.

17. Kroó, "Bornemisza", 366-367.

18. Kroó, "1968 október 11.”, 129. 
What kind of contract might lay behind the act of composition? What kind of demonic temptation longed for confession in The Sayings? Kroó for his part avoided to speak about a putative political context of the composition. He transferred the image of the pact with the devil into the framework of $20^{\text {th }}$-century music giving the impression that he meant the possibility of writing not only ugly but also beautiful new music. ${ }^{19}$ Composer András Mihály, who was one of the official proposers of The Sayings' presentation in Darmstadt, when speaking about the impact of the concerto on his Third String Quartet, used an exclusively musical vocabulary: "Kurtág succeeded in doing a miracle: he invented a $20^{\text {th }}$ century drama, and found its redempting lyric counterpart. It contains various technical devices of composition... the creation of such a tension, that comes into being through the almost unbearable, extraordinary compositional invention. Though Kurtág produces a dissolution too, and this is an act which can be compared with its counterpart, the creation of tensions. My string quartet, similarly to Kurtág's song cycle, describes the story of a life and both of us represent a dramatic 'upholding' in the sense of Beethoven: here I am, listen to me."20

It is clear that these statements are reluctant to speak about something that they want to articulate in reality. Historian János M. Rainer, when writing about post-Stalinism and the Kádár-era in Hungary, declares that public discourse was full of taboos after 1956, and the existence of society rested on informality, suppression, and pretence: "this latent frame created an own language an important part of which was silence (not-speaking), and in which nothing meant what it would de facto mean in formal (official) speach."21 The qouted statements illustrate spectacularly this act of suppressing. János Breuer, who represented the voice of the official musical politics, stated that Bornemisza spoke about a truth he believed to be the truth. This means that in Breuer's interpretation Bornemisza was not absolutely right when chastised himself and his contemporaries for their respective sins. On the other hand, Kroó who did write about a pact with the devil did not specify what kind of a devil he meant, and Mihály was talking about unbearable tensions and the dissolution which is born out of the upholding of the composer, but he did not name the source of the tensions, and the reason for the need of upholding.

The suppression in the Kádár-era emerged as a symptom of the contract signed symbolically by the communist power and the nation after the repression of the uprising in 1956. The regime offered limited welfare in a benign dictatorship, while the population avowed oblivion. But this oblivion proved to be a hard task.

19. Kroó, “1968. október 11.”, 129.

20. Bálint András Varga, 3 kérdés 82 zeneszerző [3 questions 82 composers] (Budapest: Zenemükiadó, 1986), 264

21. János M. Rainer, "Posztsztálinizmus és kádárizmus - történeti diskurzusok" [Post-Stalinism and Kádárism - Historical Discourses], in idem, Bevezetés a kádárizmusba [Introduction to Kádárism] (Budapest: 1956-os Intézet - L'Harmattan, 2011), 147-148. 
As Kurtág put it in an interview, the world had collapsed for him after 1956, and he realized that "nothing is true in my world, I haven't got any references to reality." 22 Thus it is legitimate to ask the question: could the suppression, the silence, the taboos, and the pretences have influenced Kurtág's music, a composer who did not emigrate from Hungary after 1956 but came to terms with the Kádárian mode of extistence? In The Sayings Kurtág uses symbolically Bornemisza's texts, he formulates his own experiences - as Kodály did it in his Psalmus Hungaricus - from a prophetic attitude. He speaks in cipher to avoid the direct drafting of the message, and this helps him to keep the message of the text distant, and at the same time make it universal. Is the music, which is based on different layers of meanings and references, functioning like a subtext? Does it lead its own life, does it say more than the text, or does it work against it?

András Mihály referred to the Beethovenian model of The Sayings, ${ }^{23}$ and Kroó noted that Kurtág's concerto follows Beethovenian forms. ${ }^{24}$ Kurtág remembered in an interview given to Friedrich Spangemacher, that he had prepared himself mentally for composing The Sayings through the analysis of Beethoven's last string quartets, piano sonatas, and the Missa Solemnis. ${ }^{25}$ Stephen Walsh commented that Kurtág, by his own account, wanted to compose a piano part in his The Sayings which is similar to Beethoven's Hammerklavier Sonata, and he recommended to play the two pieces on the same concert. ${ }^{26}$ As Walsh put it, Kurtág experimented in his concerto with the boundaries of the physical possibilities of the performer, as Beethoven had done it in his piano sonatas and string quartets. The fourth movement of the third part (Death) mentions for example the physical pain that precedes death. The physical pain is depicted with the almost unplayable part of the piano.

But there are other parallels, too. In the seventh movement of the second part (Sin) the piano plays trills similar to those appearing in the last movement of the Hammerklavier Sonata (Example 2a-b). This kind of allusion is not unknown in Kurtág's compositional practice. The fourth movement of the third part responds to the beginning of Penderecki's Threnodi in memory of the victims of Hiroshima, the eighth movement recalls the C-sharp minor fugue of the Wohltemperiertes Klavier, $^{27}$ the seventh movement, which speaks about the doors and their keys which lead to the death, recalls Bartók's clusters in his Bluebeard's Castle, while the devilish clock-music heard in the third movement of the Sin alludes to

22. Bálint András Varga, "Három kérdés Kurtág Györgynek," in idem, Kurtág György (Budapest: Holnap kiadó, 2009), 13.

23. Varga, 3 kérdés 82 zeneszerző, 264-265.

24. Friedrich Spangemacher, "Mit möglichst wenig Tönen möglichst viel zu sagen. Ein Gespräch mit dem Komponisten György Kurtág," Neue Zürcher Zeitung, 13 June 1998. 65.

25. Walsh, Kurtág, 669.

26. Ibid.

27. Walsh and Beckles Willson referred to the analogy between Kurtág's movement and Schoenberg's Nacht from Pierrot Lunaire. Stephen Walsh, "György Kurtág: An Outline Study," Tempo New Series 140 (March 1982), 19, Beckles Willson, György Kurtág: The Sayings of Péter Bornemisza, 100. 
EXAMPLE 2a Kurtág, The Sayings, II/7, bars 1-3

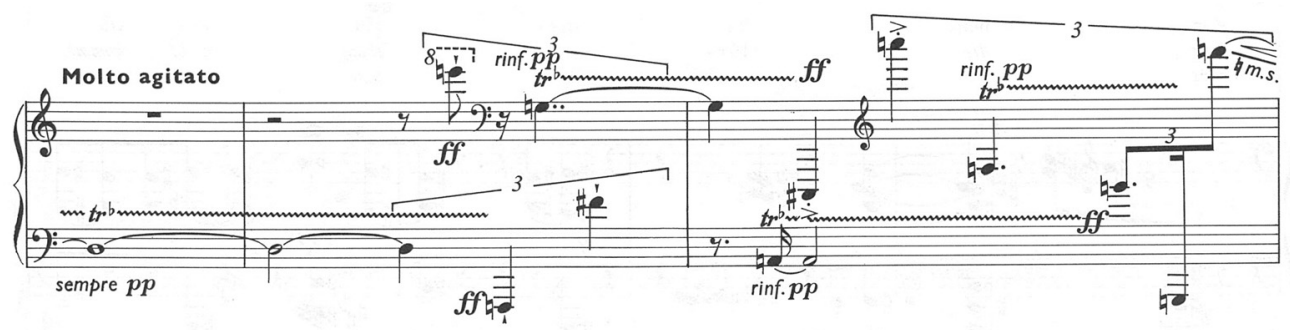

EXAMPLE 2b Beethoven, Sonata in B-flat major, op. 106 ('Hammerklavier'), $4^{\text {th }}$ movement, beginning of the fugue

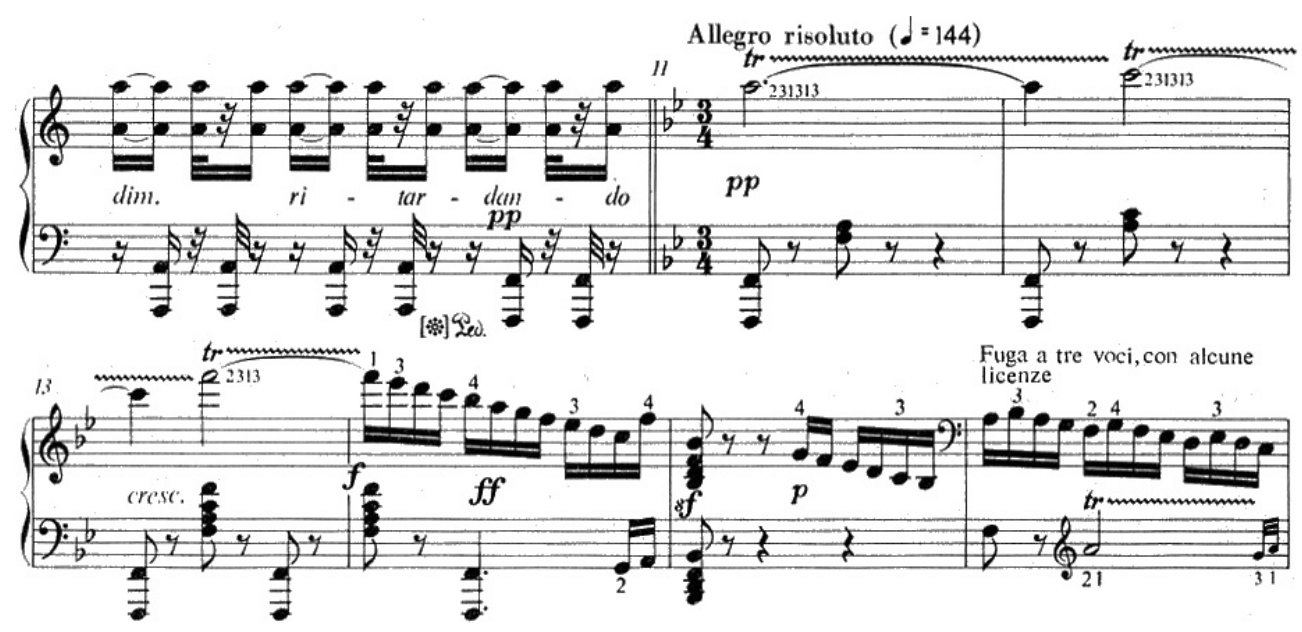

Ligeti's realisation of the same concept for example in his Poème Symphonique (1962). However, the late works of Beethoven might have had a formal influence on Kurtág's music as well. The Sayings, like Beethoven's late music, is based on different, thematically correlated movements, which partly represent the traditional sonata principle, but partly perpetually strive to dissolve it. Moreover Kurtág's music, as well as Beethoven's, is full of personal statements, like the subtitle Heiliger Dankgesang eines Genesenen an die Gottheit in op. 132, or the "Muss es sein? Es muss sein!" motto in op. 135. The latter might be considered as being connected to the artistic upholding mentioned by András Mihály.

These references in Kurtág's music, however, are coded messages, ciphers, which can be understood only by 'Kenners.' This is why The Sayings begins with Morse-signs, which at the same time can be interpreted as the scraping of pen (Example 3). This is a means of musical criptography: the beginning leads us to 


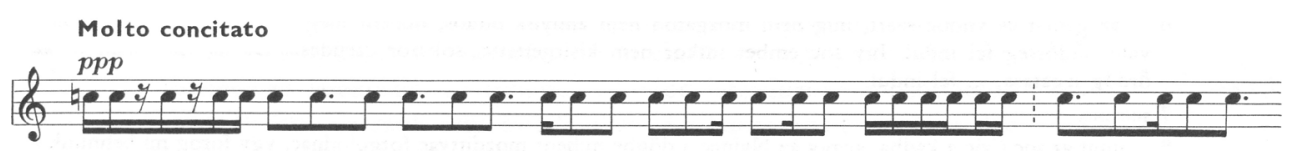

a world full of enciphered messages which must not be understood by everybody. This music was written for the initiated listener. No wonder that Darmstadtians real outsiders in the context of Hungarian music and politics - were not in possession of the ciphers. The Sayings was consciously written for Hungarian listeners, who understood the codes hidden in it.

The parallelism with Kodály's Psalmus Hungaricus becomes determining exactly at this point, as Kodály's work was written from the same position. Kurtág, when referring to Kodály, was completely aware of this. His inclination to musical illustration can be connected to Kodály's practice too, and not to Schütz or Bach, whom Kroó mentioned in his study. ${ }^{28}$ Nevertheless, Kroó when coupling Kurtág's practice with $15^{\text {th }}$-century Augenmusik, differentiated between three types of word-paintings: 1) expression of a character, 2) word-illustrations and 3) musical pictures. ${ }^{29}$ Yet Kodály preferred this kind of Augenmusik in his whole oeuvre, but the most spectacular examples can be found precisely in Psalmus Hungaricus, where - besides characters and pictures - word-illustrations play a central role. When King David is speaking about a dove, the flute plays a flying formula (bars 64-67), and when the fire is mentioned, the strings recall with their trill the picture of the flaming fire (bars 333-337).

Kurtág shows a preference for this kind of word-painting in his concerto. He depicts the fog with pianissimo clusters and arpeggios, the hardness of the stonewall with forte chords (II/1). The fish and the worms appear with restless chordrepetitions (II/8), and one can see the gesture of hoeing in the sforzatissimo tones of the piano part. The piano depicts the removal of the shit and its smell with an excited and restless movement. The most characteristic word-painting appears, however, in the last part of the piece, where the voices of animals are present as the symbol of the world's renewal in the spring. Of course, Kurtág alludes here to the old musical topos of the birth of spring and the world (appearing for example in Joseph Haydn's Creation), but the direct antecedent for the animals' voices must have been Kodály's folk song arrangement, Kitrákotty mese (Cockricoo!) from his Hungarian Folk Music. While Kodály plays with the voices of hens, chickens, turkeys, lambs, and pigs, Kurtág's music mentions wild animals, birds, cattles, hens, gooses, calves, and lambs.

28. Kroó, "Bornemisza", 346.

29. Ibid., $347-348$. 
Such illustrations are seemingly unambiguous, inasmuch as they do not hide the meaning but bring it to the surface, as if they were working against the coded content. But these word-paintings are delusive, as they capture our attention and take the listener's mind off the 'real message,' which is concealed in the thick net of musical references. The three first parts are very chromatic and dissonant, the diatonic metamorphosis takes place only at the end of the third part, when the dead are buried, thus the empire of death is reached. The appearance of diatony is prepared in the formal and tonal structure of the composition.

The first part follows a rondo form with intermezzi for the piano, the second part has got a much more free form, but there are piano intermezzi between the vocal movements. The third part uses the motto, "Flowers we are," which appears two times in this part symbolizing human fallibleness. This part comes to an end with a variation of the motto: "Delicate as a blossom is." This is the point where Kurtág turns to diatony, though he also uses a tower of fourths in the second part connecting it to the word "thee" (Example 4a). That means, that the other is much more well-balanced, harmonious, than the self. This tower of fourth will return in the summing up of the whole composition in the fourth part (Example 4b).

EXAMPLE 4a Kurtág, The Sayings, III/2, bar 3

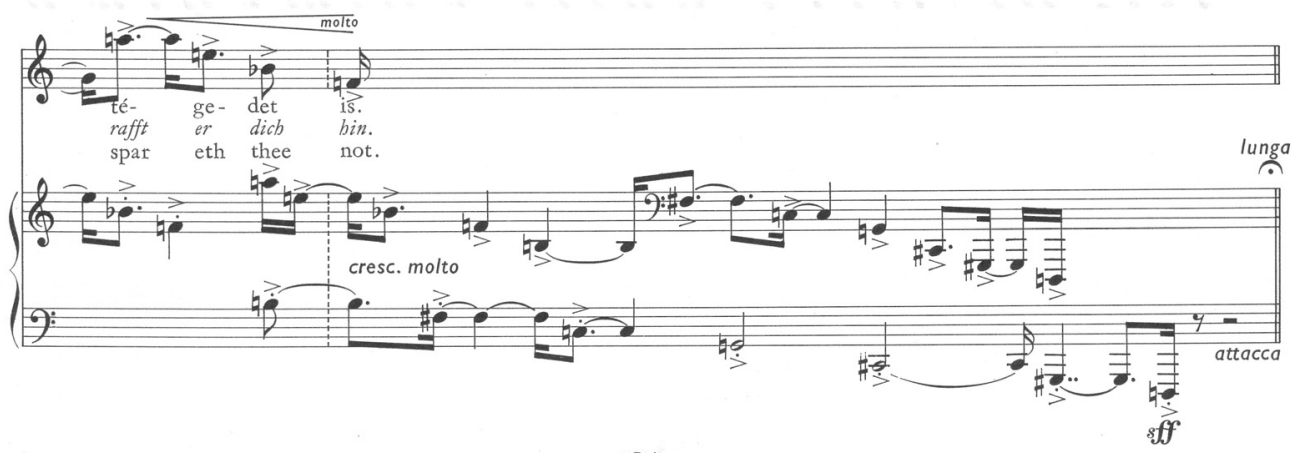

EXAMPLE 4b Kurtág, The Sayings, IV/3, bar 17

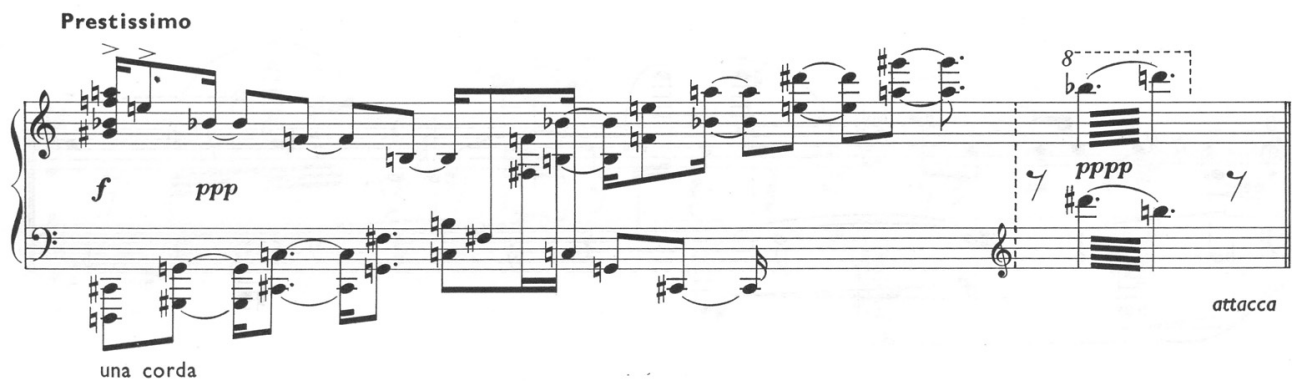

Studia Musicologica 54, 2013 
EXAMPLE 5a Kurtág, The Sayings, III/6, bars 15-16
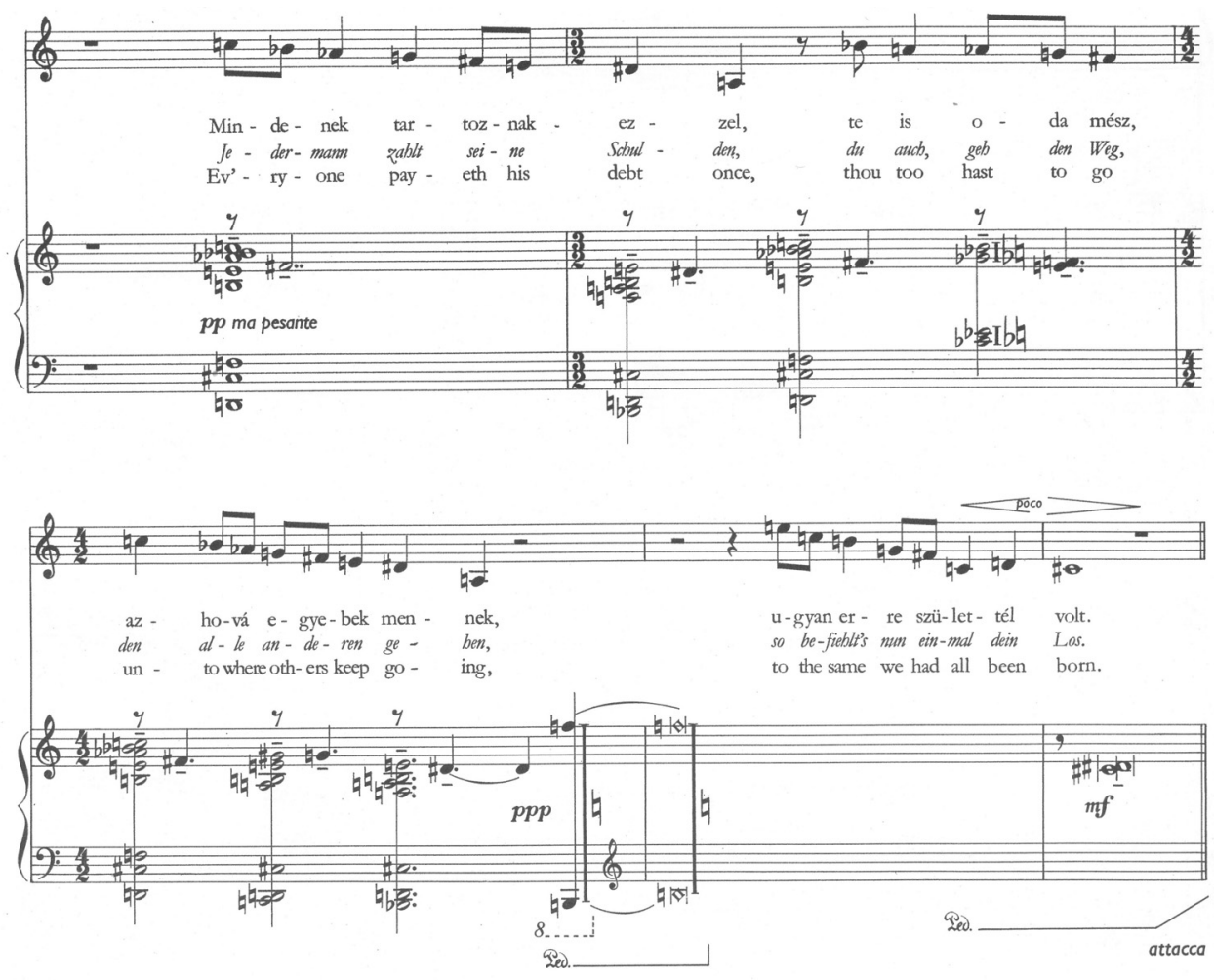

The second diatonic seed, a diatonic scale, appears in the sixth movement of the third part (Example 5a), but it is preceded by the piano solo of the ninth movement of the second part (Example 5b). Eventually, in the fourth part this diatonic scale (f-e-d-c-b-a) becomes the symbol of spring (Example $5 c-d$ ). The third diatonic element is represented by thirds and sixths, which appear in the seventh and eighth movement of the third part, and are serving as the main motivic seeds for the last part.

This structure, which leads from chromaticism to diatony, might even support György Kroó's interpretation, that Kurtág's music shows the possibility of a diatonic reconciliation. As Peter Hoffmann put it, when writing about Kurtág's first string quartet, Kurtág's music can be understood as a constant search for the C-major chord, as a symbol of purification. ${ }^{30}$ Kurtág himself said about it that one 'has to deserve' $\mathrm{C}$ major, the symbol of harmony. ${ }^{31}$ But to deserve this musical and

30. Peter Hoffmann, “'Die Kakerlake sucht den Weg zum Licht.' Zum Streichquartett op. 1 von György Kurtág,” Die Musikforschung 44/1 (January-March 1991), 32-48, 46.

31. Bálint András Varga, "A három kérdés - még egyszer" [The three questions - once again], in idem, Kurtág, 36-38. 
EXAMPLE 5b Kurtág, The Sayings, II/9, bars 1-11
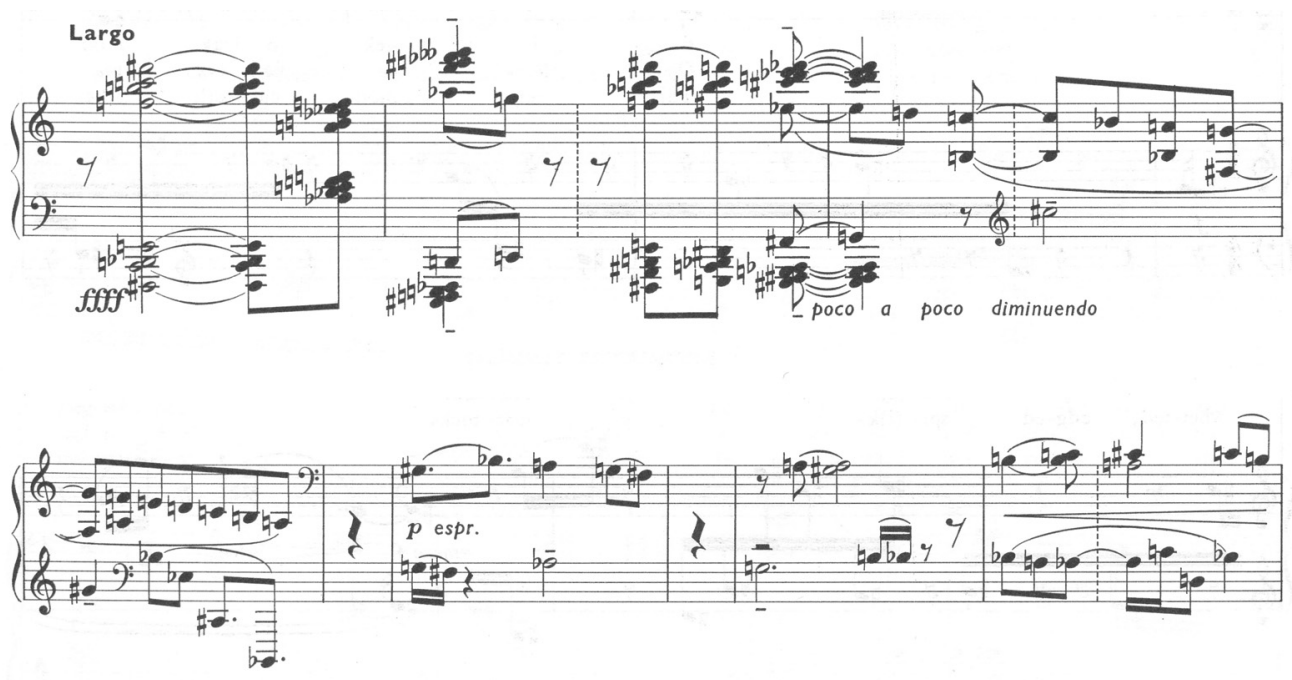

EXAMPLE 5c Kurtág, The Sayings, IV/3, bars 27-32

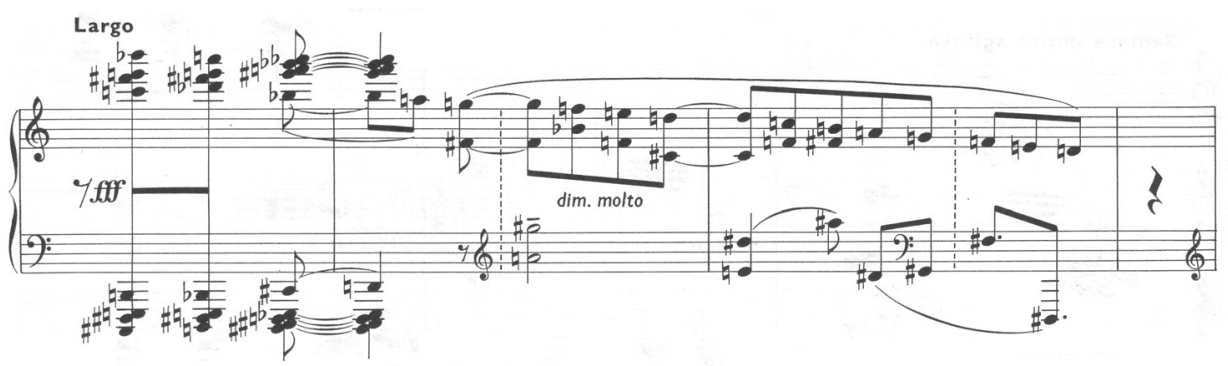

Example 5d Kurtág, The Sayings, IV/4, bars 78-80

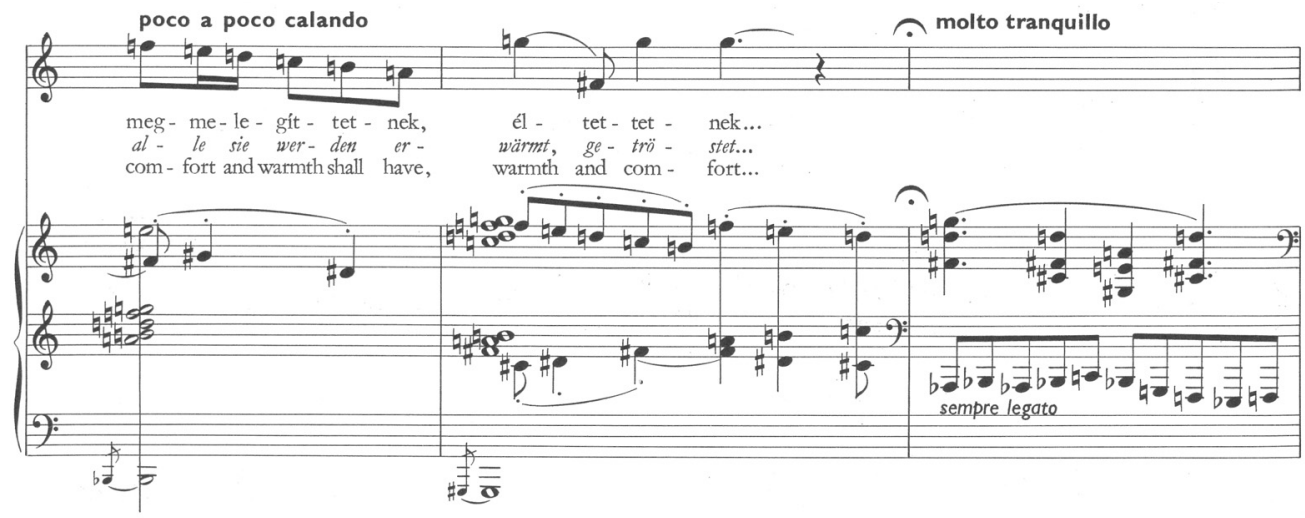

Studia Musicologica 54, 2013 
spiritual harmony one has to be conciliated, and conciliation can only come after experiencing sin. For Kurtág, as for his Hungarian contemporaries, sin was connected to the symbolical contract bound with the political power. The contract as a condition for Hungarians practicing double speech at that time - made it impossible to speak about the truth which was expressed in ambiguous ciphers or suppressed words. In this respect The Sayings of Péter Bornemisza represents György Kurtág's Hungarian identity. 